\title{
PEOPLE LIVING BY CHANGING SEAS. MESOLITHIC COASTAL SETTLEMENT ON THE WEST SIDE OF THE BALTIC SEA
}

\section{LARS LARSSON}

\begin{abstract}
Selected find spots along the Swedish coast of the Baltic Sea are presented, in order to illustrate different ways in which hunter-gatherer societies related to the coast during the Mesolithic. Transformations of the landscape were mainly due to isostatic and eustatic changes. In the northern part, the land rose, forming new coasts and archipelagos at a speed that was noticeable even within one generation. Similar rapid changes occurred in the southern area, but in the opposite direction, with large areas of coast being submerged. Both physical and mental reactions to this are explored.
\end{abstract}

Key words: Mesolithic, hunter-gatherer, coastal settlement, coastal-inland relationship.

DOI: http://dx.doi.org/10.15181/ab.v25i0.1829

\section{Introduction}

Settlement in and around the Baltic Sea is an extremely wide field of study. A considerable amount of research has been done, but much more remains to be investigated. This presentation will focus mainly on the early and middle Holocene, with an emphasis on the Swedish side of the Baltic Sea, from central Sweden and further south (Fig. 1). In this context, the western part of the Baltic Sea includes the Öresund strait and its course towards the North Sea.

As the title of the article indicates, the presentation concentrates mostly on the changing landscape that people exploited during the Mesolithic. It should be borne in mind that the chronology concerns the Mesolithic as we know it in Scandinavia, that is, 10000 to 4000 BCE (all dates are calibrated).

By far the greatest change in the coastal landscape was the displacement of the shoreline, which at this time was patently obvious to the coastal population.

Several geologists have described the course of displacement of the shoreline (Andrén et al. 2011; Rosentau et al. 2017). We therefore have a general picture of how the relationship between the land and the water changed. But this does not mean that the situation of the coastal population has been clarified. Several factors to do with isostasy and eustasy are far from being solved. When a section of the coast literally rose out of the sea, and in other places vanished below sea level, it entailed both disadvantages and advantages. In the former situation, it meant that settlements could, if people wanted to, claim new land. In the latter, settlers were forced to move up in relation to the changing coastline. When the land rose, especially in areas with relatively low topography, difficulties included redirecting sea routes near the coast, but there were also advantages with the extension of the archipelago off the mainland. In areas with a rising sea level, this did not necessarily mean any shortening of the coastline. Sometimes the topography could change, to form headlands and bays (Larsson 1997).

To make the study of shoreline displacement even more difficult, we also have to bear in mind the changes that affected regional land masses. The best-known example is the one from southern Scandinavia that tilted an area extending from northwest to southeast, so that northern Jutland underwent an uplift, and northern Germany sank by up to six metres (Hartz et al. 2014). I know of no other, but it cannot be ruled out that there were several similar shifts of the bedrock which have not been observed because of larger isostatic and eustatic changes. Along shallow coasts, such changes may have had a significant effect, even if they were not on the same scale as on the north German coast.

We need to learn more about the various consequences of isostasy and eustasy, besides the well-known situations of shoreline displacement (Rosentau et al. 2011). One question concerns the way in which land and water quality was affected. Land which literally rose from the sea could, in certain areas, consist of clean bedrock, in others of nutrient-rich sediment where the potential for coastal settlement varied. What was the result further south in the Baltic Sea basin when large sections of dead vegetation near the coast were washed out to sea? As regards the latter, did this change give new nutrition to the marine fauna and flora, or were there periods with a kind of over-fertilisation, with the effects that we are so familiar with today? There are factors

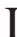

STONE AGE IN NORTHERN EUROPE: CHANGES IN LANDSCAPE, TECHNOLOGIES AND BELIEFS 


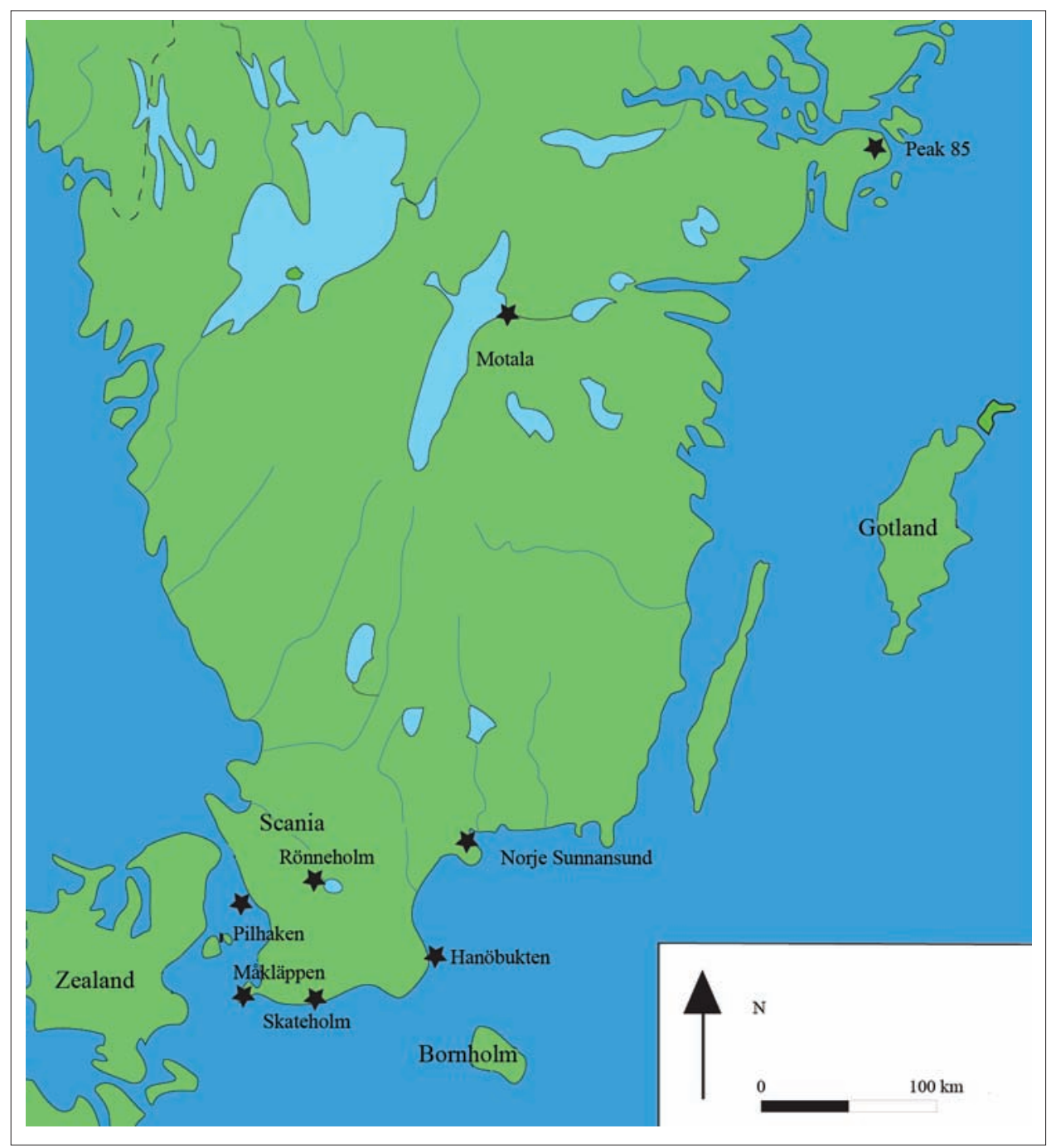

Fig. 1. The Swedish Baltic Sea coast, with the locations of sites mentioned in the text (drawing by Lars Larsson).

here that may have had significant effects on fishing and on hunting for marine animals, and these are aspects which have not been sufficiently illuminated.

The distribution of flora is relatively well attested to today for the southern part of the Scandinavian peninsula. But there are doubts about some aspects of the distribution and reproduction of the fauna. This applies in particular to fish species and marine mammals that require closer scrutiny.

During the early Holocene, there were radical changes in the large basin that today is the Baltic Sea, with its inflows and outflows. The composition of the water, for instance with varying salt content, likewise underwent significant changes (Andrén et al. 2011). This may have had the effect that different fish species, as well as marine mammals and probably also sea bed vegetation, had varying conditions for becoming an integral part of the ecosystem. Fish that migrated between different ocean basins, and also between salt wa- ter and freshwater, may have been noticeably affected. We do not know how many generations of a species it took to change its behaviour. In this process, the size of a population may have been seriously reduced. This concerns the migration of salmon to areas which in modern times have been well known for this fishing, but which were probably not in the early Holocene. Unfortunately, our knowledge of, say, populations of seal species in the Baltic Sea is still relatively limited (Schmölcke 2008).

People's use of the coast is not exclusively dependent on isostatic and eustatic conditions, but is also affected by what happened well inland from the coast. It has long been believed that thicker forests in the Atlantic period led to reduced fauna, and thus made coastal hunting and fishing more important (Schmölcke 2006). But is this the whole truth? Active burning (Mason 2000; Anderson 2005) and reduced hunting for beaver, which built dams and changed significant areas (Larsson 1983a; Coles 2006), may have led to considerable 
open sections in the forests, with good opportunities for more animal species to increase, and thereby become attractive for humans.

Our knowledge of climate variations in the Baltic region is also rather limited. We know a lot about the change in $8.2 \mathrm{ka} \mathrm{BP}$, but smaller changes may also have had palpable consequences (von Grafenstein et al. 1998; Rasmusen et al. 2007; Crombé 2017; Griffiths, Robinson 2017). Changes in temperature, precipitation, waves and currents ought to be an important research field in the future (Bond et al. 2001; Brooks, Langdon 2014). How changes in sea level and variations in precipitation affected the groundwater for lakes near the coast and further inland is almost unknown. For example, the water in Lake Ringsjön in the interior of Scania, in southernmost Sweden, may have been so low in the Late Boreal period that the lake had no outflow (Nilsson 1967). This would have had negative consequences for the inland as an interesting area for hunting and fishing, and it would also have affected coastal settlement, with a drastic reduction in the outflow of freshwater.

An attractive area for settlement appears to have been the estuaries of both large and small rivers. The form these took, and the ecological structures they formed, were highly dependent on their drainage areas, affected by climatological conditions, but also changes to land further inland, such as lakes turning into bogs.

Another factor that ought to attract more attention is the question of the structure and size of settlements. We know from ethnographic parallels that a settlement does not affect exclusively the area that is used every day by the inhabitants, but also comprises considerable areas around it, where different activities leave traces in the landscape, which are very difficult to detect by archaeological methods (Grøn 2012). It may be the case that the choice of settlement site was not always linked to the conditions in that exact spot, but chiefly related to the shortest distance between other factors, such as access to fresh water, firewood, raw materials, etc.

Knowledge about catching methods also raises some interesting aspects, for example, catching fish by methods reflected in finds such as leisters and harpoons, as well as fixed trapping devices. Around 5500 to 5000 $\mathrm{BCE}$, people in certain areas stopped making leisters out of bone and antler, and switched to making them out of wood (Klooß 2015; Larsson et al. a). Was this due to new fishing methods, or to a change in preferences, for example, from pike to eel? How is coastal leistering related to permanent trapping devices? It has long been thought that the permanent devices did not arise in southernmost Scandinavia until the Atlantic pe- riod. Recently, however, one device was discovered in a Preboreal coastal environment (Hansson et al. 2016) (Fig. 6). For most questions that have been asked, there are no unambiguous or even acceptable answers; yet it is important to ask the questions.

We must also remember that there is a significant difference between the northern and southern parts of the Baltic Sea coast. In the north, the soil layers are mostly acidic, which means poor preservation conditions for organic material; whereas the soils in the southernmost parts are more basic, and thus preserve a varied range of organic remains, yielding much more archaeological material.

\section{Eastern central Sweden}

Probably the first settlers came to this area from the east coast of Sweden. Datings indicate that this may have happened relatively quickly, and that the oldest settlement in central Sweden was established slightly later than 8000 BCE (Pettersson, Wikell 2006, 2013). Of special interest is the research dealing with the utilisation of the outer archipelago. One might think that this resource ought to have been the last resource that was used, but this is far from certain. Pettersson and Wikell have carried out an extensive survey of the highest locations in the present mainland and the archipelago, and have found seal bones and something they call 'blubber concrete' on settlement sites that make radiometric dating possible (Persson, Wikell 2013, 2014). It was mostly grey seal that was hunted, but there are also finds of ringed seal. At levels around 75 metres above sea level, such as Peak 85 , they found settlement sites and also hut sites which show that these sometimes small skerries were part of a network of regularly used places around 7500 BCE (Fig. 2). They have been found to be extremely rich in quartz waste, which indicates that they were used intensively. And it should be borne in mind that some of these skerries were located up to 120 kilometres from the mainland. In occasional cases, the skerry was not even visible from the nearest island. People had such seagoing experience that they dared to steer towards unknown land. Even if it may have been frozen during the winter, archipelago hunting in later periods shows that people did not venture out too far without boats, because the wind and currents could transform an ice field into drift ice.

Although the outer skerries and islands were used for seal hunting, the settlement sites on the bigger islands are related to freshwater lakes, which indicates the significance of freshwater fishing.

The archipelago on the Swedish side did not reach out as far as it does today, and the same is true of the Finn-

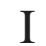

STONE AGE IN NORTHERN EUROPE: CHANGES IN LANDSCAPE, TECHNOLOGIES AND BELIEFS 


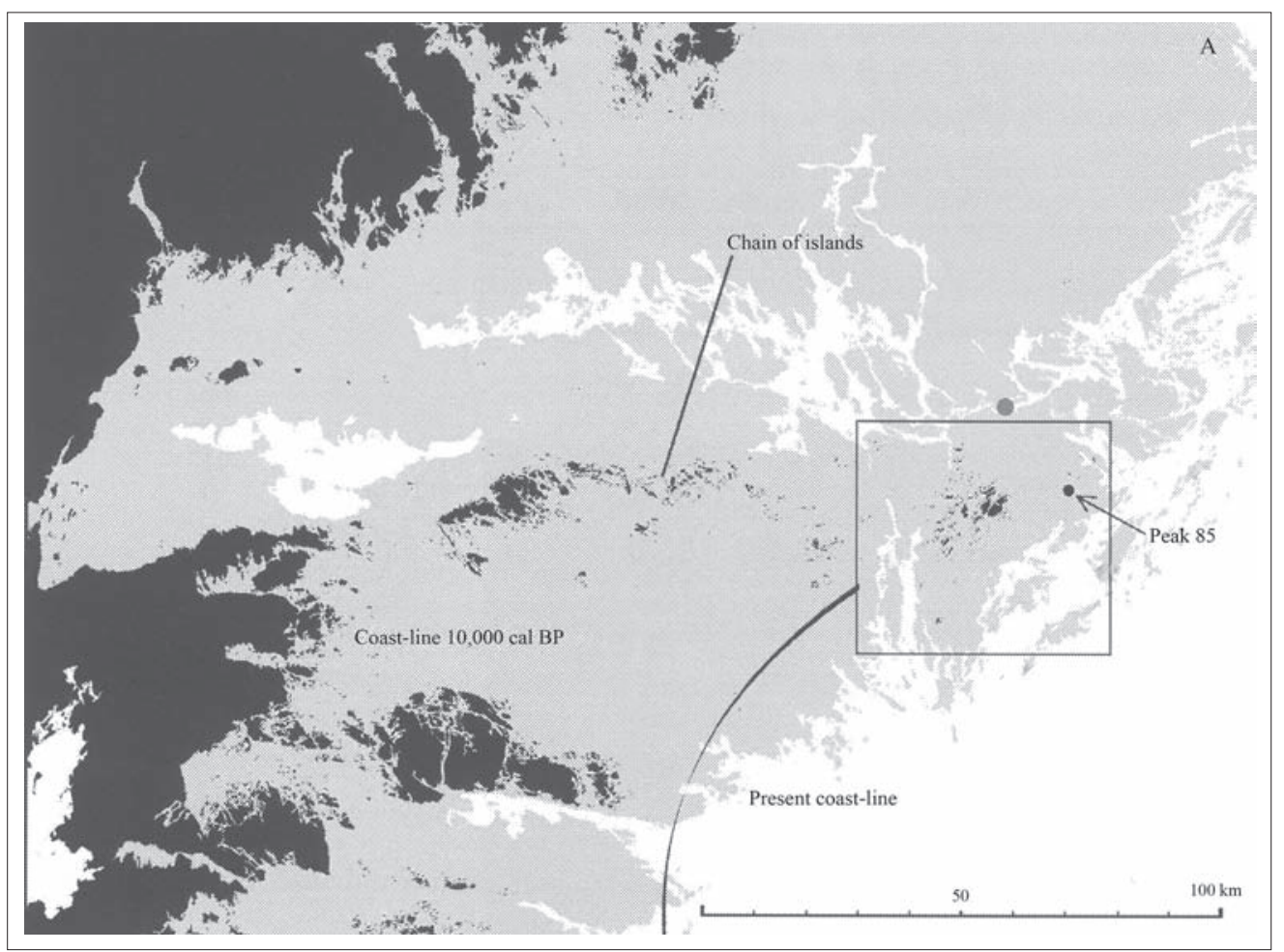

Fig. 2. The situation in east central Sweden at about 8000 BCE (from Pettersson, Wikell 2013).

ish side. But one may suspect that, with the extensive knowledge they had at a very early stage, people might have established temporary or more regular eastern contacts. New knowledge about flint technology shows that new ways of producing micro-blades were clearly of eastern origin (Sørensen et al. 2013; Knutsson et al. 2015). This technique is closely associated with bone tools in the form of slotted bone points and daggers, where the micro-blades functioned as effective edges (Zhilin 2015). Both the flint technology and new forms of bone and antler tools may have been conveyed through the channels that arose when seal hunters, as a result of the expansion of the outer archipelago, met hunters from the other side of the Baltic Sea (Larsson, Molin 2017).

It should also be borne in mind that land uplift may have affected the way in which seals were hunted. A change in the outer archipelago may have led to a change in the migrations of seals during the annual cycle, forcing the hunters to seek their prey on islands other than those used previously (Pettersson, Wikell 2006).

\section{The island of Gotland}

The island of Gotland is another interesting case (Fig. 1). Extensive archaeological and osteological studies in recent years, under the leadership of Apel, have examined the earliest settlements (Apel et al. 2017).
These have shown that the island was populated around 7200 BCE. Based on radiometric dates from several find spots, it has been demonstrated that the first phase of settlement was intensive. The location of settlement sites and the osteological material show that what primarily attracted people was fishing in the big, nutrient-rich lakes that existed on the island at the location of the oldest settlements (Boethius et al. 2017). Even coastal settlement sites have a limited amount of seal bones. The island had no large fauna. When the lakes filled up with vegetation in the early Holocene, it seems that there was a declining interest in settling on the island. There does not seem to have been any great need to use the marine resources on a more permanent basis. In the later part of the Mesolithic, there does not appear to have been any permanent settlement. This has been interpreted to mean that it was used for seasonal journeys from the western mainland 80 kilometres from the island. If so, this ought to mean that people had large vessels that enabled safe crossings. There is no sure evidence as yet that people travelled to the island from the Baltic mainland. Excavation results show that during the Early Neolithic, there was once extensive and permanent settlement by farming groups on the island due to the fertile soil.

Investigations on Gotland, and in other parts of the Baltic Sea, show that freshwater fishing played a very large part in the early Mesolithic, even in coastal environments. We know this partly because new excava- 
tions have used finer-mesh sieves and isotope analyses (Boethius et al. 2017).

On the west coast of Sweden, there are both terrestrial and limnic remains of animals and fish (Nordquist 2005). Despite this, the settlers have a C13 value showing that the diet consisted in large part of marine resources.

\section{Settlement by an inland sea}

For several years, there have been archaeological excavations at Strandvägen, Motala (Fig. 1), in an area beside the River Motala Ström, the only major outlet from the large Lake Vättern into the Baltic Sea, which at that time, circa $5500 \mathrm{BCE}$, was about 30 kilometres to the east (Carlsson 2008; Molin et al. 2014) (Fig. 3 $\mathrm{a}, \mathrm{b})$. It is entirely correct to call this a coastal settlement, as Vättern is not just any small lake (Larsson 2005). It is Sweden's second largest lake, almost 1,900 square kilometres in area, with an average depth of 40 metres. From this point of view, not least in relation to the area of water in the southern Baltic Sea in the early Holocene, it can be perceived as an inland sea. Vättern is also notorious for the storms that can arise suddenly, with high waves, which in modern times have caused several shipwrecks. Living beside Vättern must have entailed a relationship with the water very similar to that on the coast of the Baltic Sea. Here we have a special position for the coastal population, with a relatively short distance between two large water basins linked by a major watercourse. Movement between the Vättern settlers and those on the Baltic coast might have been like leaving one coast for another, partly different one. Whether or not this led to closer contacts, or caused serious conflicts, is an aspect that deserves more research.

As we saw earlier, organic traces of settlements are extremely limited in central Sweden, where only a few objects have been found in the wetlands. But the situation has changed following the excavations at Strandvägen.

Lake Vättern was isolated from the Yoldia Sea at about 8800 BCE (Swärd et al. 2017). Through several changes, the main outlet on the River Motala Ström first formed circa $7200 \mathrm{BCE}$, triggering a lowering of the level of the lake until it stabilised at circa 5800 BCE. The occupation of the settlement was at its most intensive between circa 5500 and 5000 BCE (Carlsson 2008; Molin et al. 2014; Larsson, Molin 2017).

A considerable part of the site has been excavated, including the refuse area below the present shoreline, the lower slope of a ridge, with the remains of the set- tlement proper (Molin et al 2017), and the top of the ridge, with a cemetery (Fig. 4). This structure corresponds to the division that can be identified at Late Mesolithic coastal find spots in southern Scandinavia (Larsson 1995, 2004).

The present shoreline is the same today as during the time of settlement. By pumping the water from an artificial enclosure covering the refuse area, it was possible to expose a large number of organic finds, including many tools made of bone and antler (Gummesson, Molin, forthcoming). The Strandvägen settlement is the only one in the central part of Scandinavia with such a large number of tools made from bone and antler.

The combination of ecological conditions that existed around the site was extraordinary, with excellent fishing conditions at the outflow of the river, as well as on the large lake, and with hunting as well as gathering possible in the fertile forests surrounding the site. The location of the site was exceptional, as it was easily accessible from the south and the north, as well as from the east and west by rivers, lakes and the sea (Carlsson 2008). Raw materials, including flint of different types, and slate tools, testify to western contacts from about 100 kilometres away, almost 200 kilometres to the northeast, and more than 350 kilometres to the south (Carlsson 2008; Knutsson et al. 2015).

Just a few hundred metres to the north of the settlement across the river, a platform of stones was constructed in a small shallow lake (Gummesson et al. 2018). Within this platform, a number of human remains, mainly skulls, were found. Some of them were arranged on stakes. They date roughly to the same time as the settlement, and were interred within the settlement. Strontium analyses showed that five out of six of the interred individuals in the cemetery related to the settlement have a ratio consistent with a local provenance (Eriksson et al. 2018). However, seven out of the eight humans from the small lake are of non-local origin. The measurement of stable isotopes might indicate a certain consumption of marine food. That could be interpreted to mean that most of the heads on stakes belonged to foreigners, perhaps some originating from the east Baltic coast, who were killed when confronting the settlement.

\section{An Early Mesolithic settlement in the coastal zone}

Contract excavations at Norje Sunnansund in southeast Sweden (Fig. 1) uncovered a large settlement site from the Early Mesolithic, dated to between 7600 and 6600 BCE, although the duration of the settlement may have been much shorter (Kjällquist et al. 2016) (Fig. 5). It is

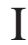

STONE AGE IN NORTHERN EUROPE: CHANGES IN LANDSCAPE, TECHNOLOGIES AND BELIEFS 

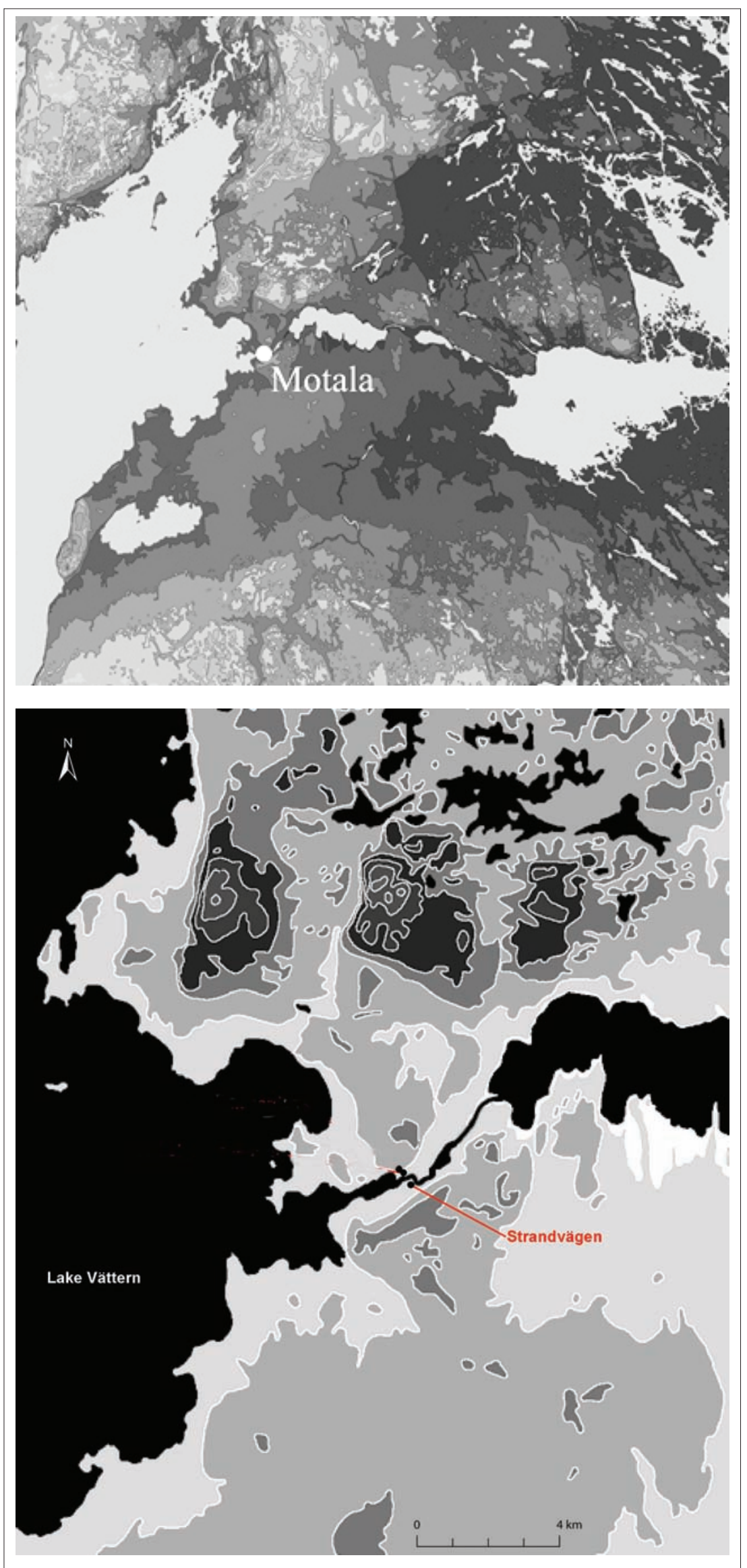

Fig. 3. Southeast central Sweden at about $5500 \mathrm{BCE}$ (a), with the location of the Strandvägen, Motala, site, at the outflow of the large Lake Vättern (b) (partly from Molin et al. 2017). 


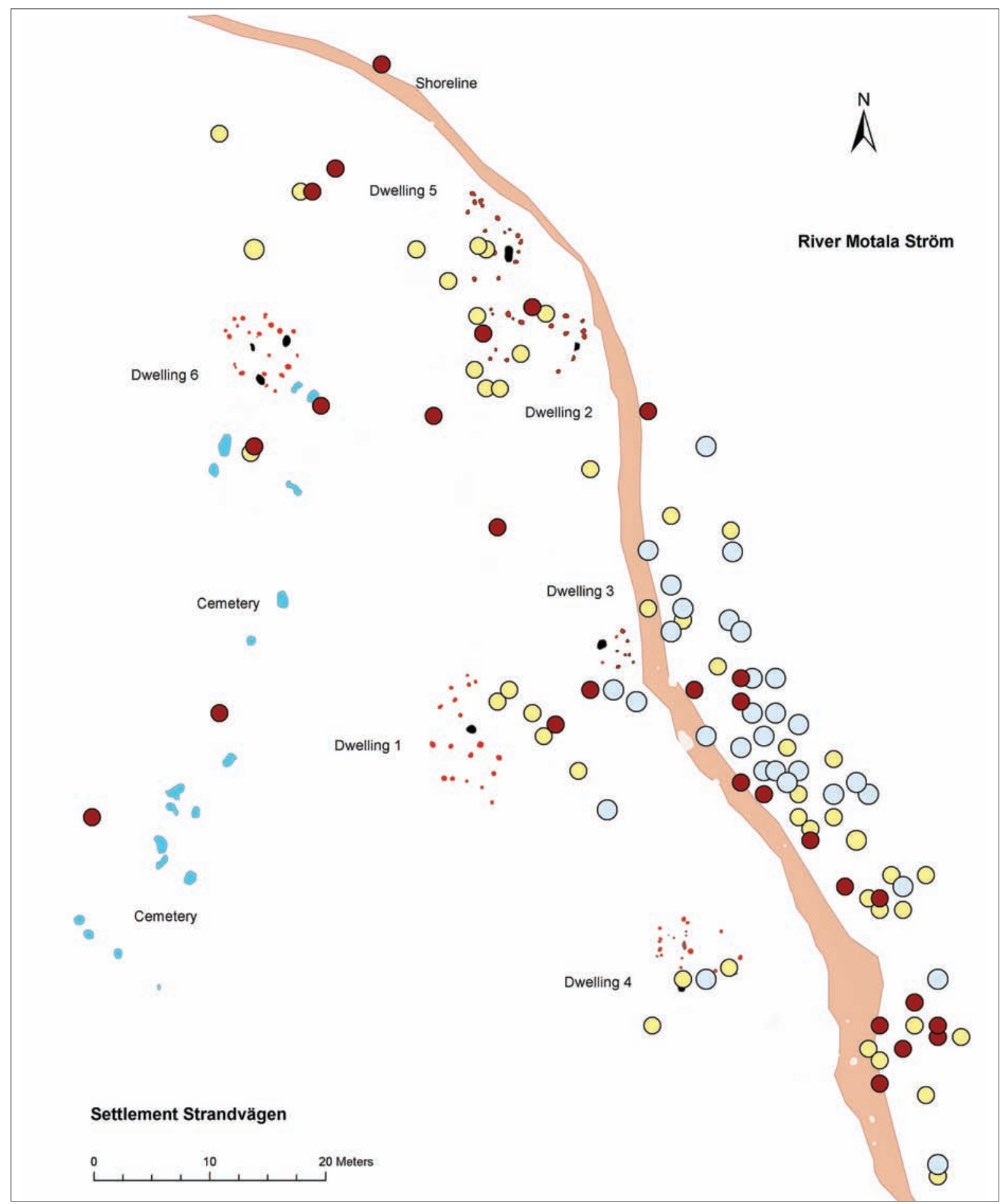

I

STONE AGE

IN NORTHERN

EUROPE:

CHANGES IN

LANDSCAPE,

TECHNOLOGIES

AND BELIEFS

Fig. 4. A site plan of the Strandvägen settlement, with the location of the Mesolithic cemetery and documented dwellings marked along the bank of the River Motala Ström. Blue and yellow dots indicate ornamented bone and antler objects. Brown dots indicate deposited 'loose' human bones (graphics by Fredrik Molin; from Larsson, Molin 2017). 


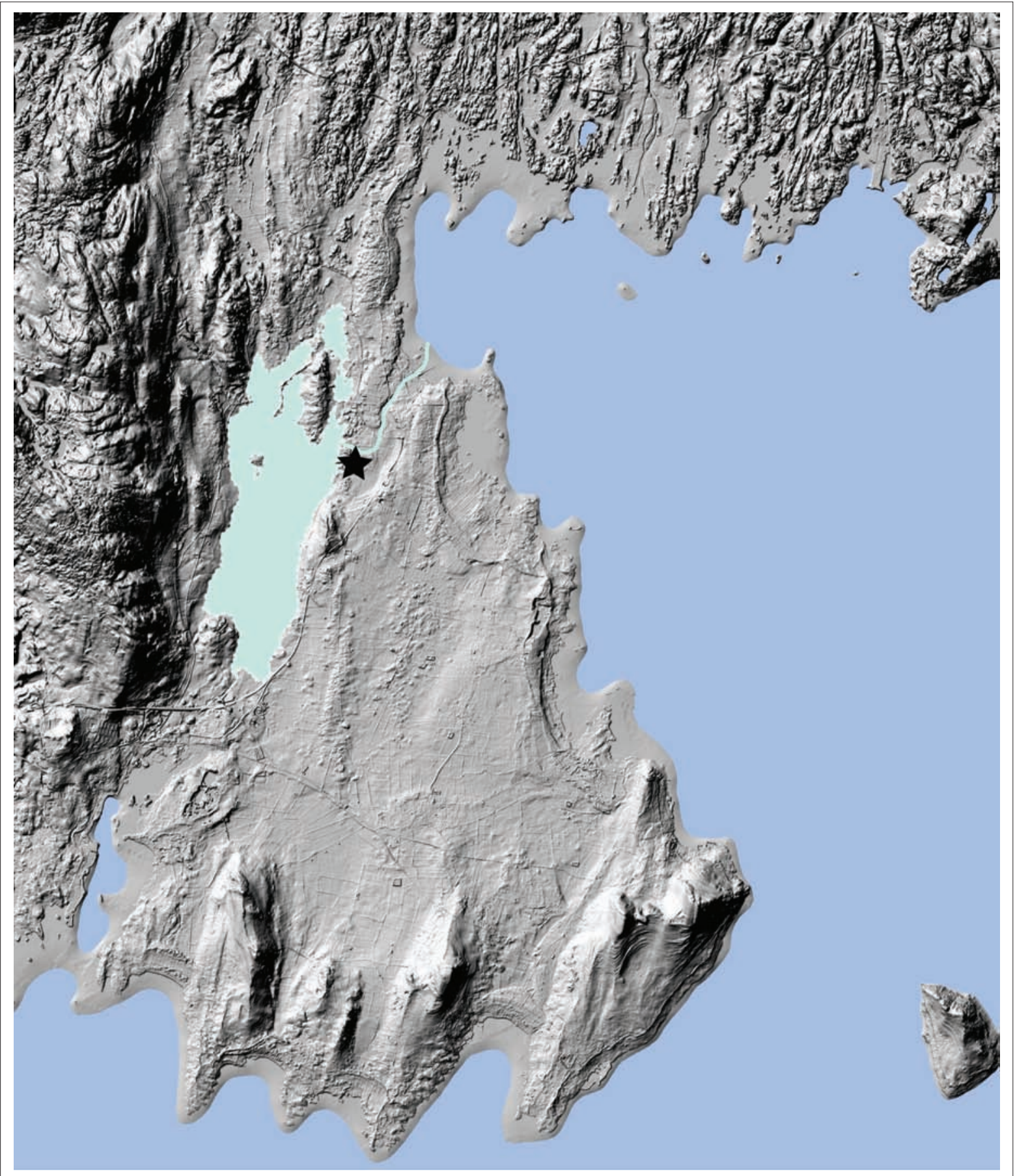

Fig. 5. The location of the Norje Sunnansund site at about 7100 BCE. The sea level is estimated at 2.3 metres above sea level (map by Nils-Olof Svensson, Kristianstad University, based on LIDAR-data from Lantmäteriet [C Lantmäteriet i2012/892], SGU data and IOWTOPO2 [Seifert et al. 2001], with permission from Blekinge Museum).

of special interest that this place was not located on the coast, but beside a small lake with an outflow a couple of kilometres from the coast. There is a large amount of osteological material, and it has been interpreted in detail. Rich finds of seal show that the inhabitants' diet was based in part on hunting for marine mammals (Boethius 2017). There are very young ringed seals which were born on the ice, an environment that must have been unusual for this time, although there is the exception of the cold period around 8200 BP. Osteology can thus give a hint of the situation a century or so after this sudden change in climate.

A structure built for the fermentation of fish has been identified (Boethius 2016). This gives proof of a method for long-term preservation, confirming long-held suspicions that it must have been practised. We cannot 
determine the extent of fishing in the sea, since at the time of this settlement it consisted of fresh water, and hence the same species were found there as in the lake beside the settlement site.

Norje Sunnansund is the only Early Mesolithic site where there is good evidence of year-round settlement, and in fact the only one with confirmed indications of winter hunting. The fact that permanent settlement occurred during the Late Mesolithic is accepted by most scholars (Rowley-Conwy 1983, 1993; Rowley-Conwy, Zvelebil 1989). The finds from Norje Sunnansund are evidence that permanent settlements with food preparation for a delayed-return economy existed, along with deliberate selection of prey, much earlier than was previously assumed.

It may be of special interest that the settlement site was located a couple of kilometres inland from the coast. Similar locations have not hitherto been considered as typical choices for coastal settlements (Fischer 1995). This gives us pause for thought. There has been criticism of the investigation methods (Grøn 2012). Have we been too restrictive, only searching for coastal settlement right on the shoreline, or does Norje Sunnansund represent a location that differs from most other sites?

\section{Submerged landscape and settlement}

Along the south coast of Sweden, the situation is that the sea drowned the land, with the result that we have only a few find places discovered by underwater archaeology. The most recent archaeological and geological investigations of Hanöbukten Bay on the east coast of Scania have yielded very interesting results concerning shoreline displacement and human utilisation of the coastland (Hansson et al. 2016, 2017a, 2017b) (Fig. 1). There is a special significance in the thick layers of peat found at a depth of at most eight metres, enabling studies of shoreline displacement during a significant part of the Holocene. In an early part of the Holocene, the area up to a depth of 20 metres was overgrown with pine, and the lower parts of the trunks still rise over the bottom. A lagoon area has been demonstrated where there were remains in several places of stationary trapping devices for fish, dated to between 7000 and 6400 BCE (Fig. 6). They are the oldest known in northern Europe. No clear settlement layer has been found, but an antler axe, aurochs bones with cut marks, and wooden torches provide clear evidence of human presence. These investigations of submarine remains from the early Holocene lead us to hope that similar environments for settlements, and with better preservation and limited erosion, can still survive within the land masses that used to exist in the southern Baltic Sea. Extensive areas of land, probably one third of the present-day southern Baltic, were submerged during the early Holocene. This must have caused significant changes in the conditions for coastal settlement and the ecosystem.

\section{An island takes shape}

The formation of what today is Bornholm is an interesting case. According to the seabed topography, the area between the present island and the continent used to be solid ground (Sørensen, Casati 2015). There is a large area here, bigger than the whole present island of Bornholm, which was submerged in the Early Holocene (Fig. 7). Many square kilometres were gradually flooded by water, which varied, depending on the opening or closure of water routes to the present North Sea, between fresh, brackish and salt. There should be places on the bottom which could be interesting to survey. This transformation took place in an early part of the Mesolithic, when the regional variation in material culture was rather limited, which makes it difficult to distinguish between the southern limit of today's Baltic Sea in present-day Poland and the northern limit of the Baltic Sea in Scania.

As regards the latter, Bornholm is visible from the coast of Scania, and in view of the evidence for considerable sea transport as far back as the Early Mesolithic, there must have been contacts between the mainland in the north and the northernmost points of continental Europe to the south.

\section{Coastal-inland contacts}

The relationship between the coast and inland can be exemplified by finds in central Scania, southernmost Sweden. A survey of a large peat bog, Rönneholms Mosse, found both typical bog settlements and small, very short-lived campsites (Larsson, Sjöström 2011, 2013).

At a couple of bog sites, strange accumulations of small flints have been found, almost square and usually wave-washed (Fig. 8). The explanation is that they were attached as weights to nets that have decomposed. Since flints do not occur inland, nets with weights must have been made on the coast and then ended up inland through actual movements by coastal people, or through exchanges between groups. Further evidence of contact comes from a find in the Rönneholm bog of a piece of jewellery with nine perforated shells of Nassarius reticulatus, a marine gastropod mollusc. In this case, the eastern coastal area of the Öresund strait, at a

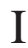

STONE AGE IN NORTHERN EUROPE: CHANGES IN LANDSCAPE, TECHNOLOGIES AND BELIEFS 


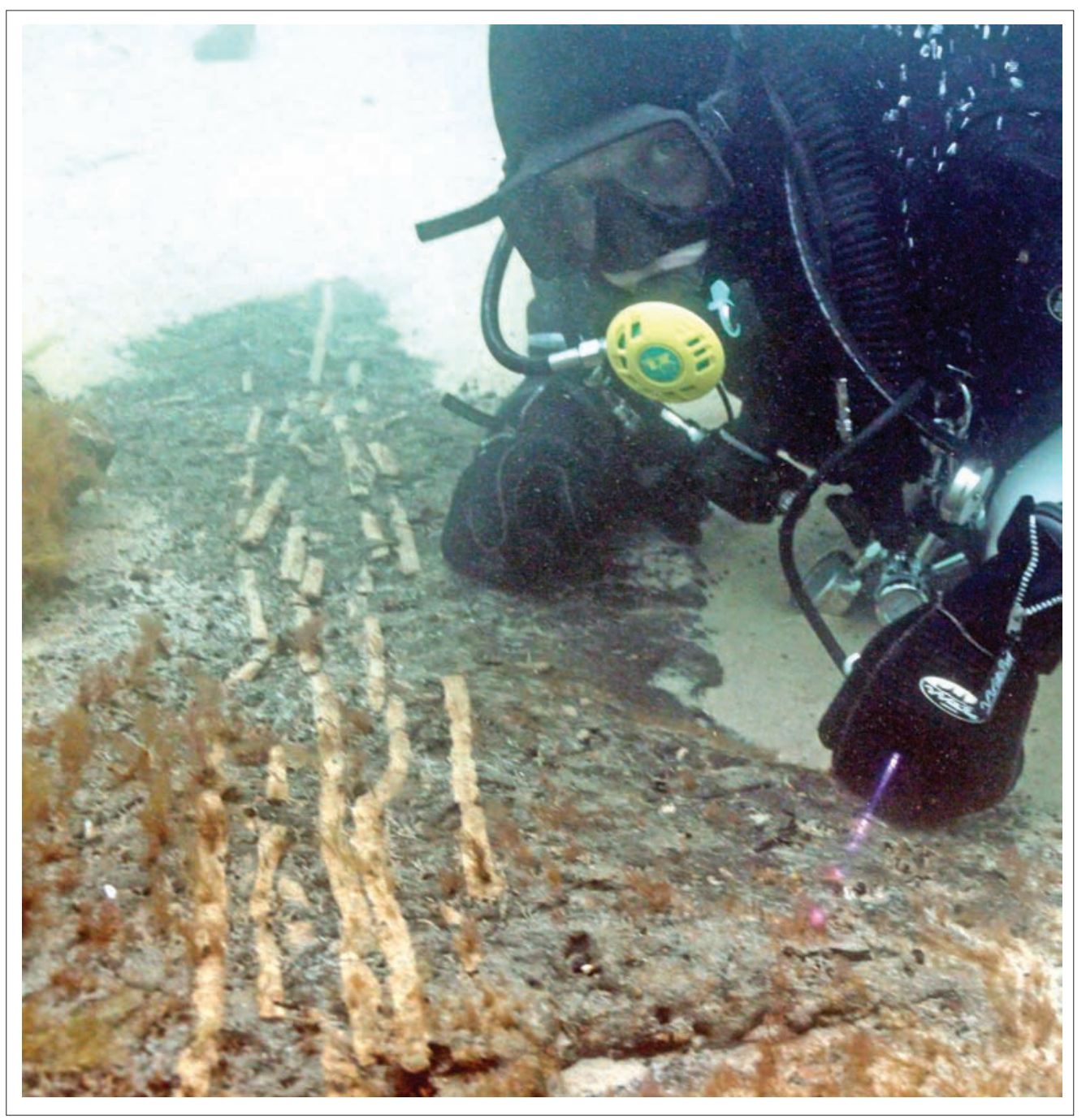

Fig. 6. The remains of a stationary trapping device from the bed of Hanöbukten Bay (photograph by Arne Sjöström).

distance of more than 30 kilometres to the west, is the most likely origin of the flint pieces and the shells, as the river flowing through Rönneholms Mosse ends up in northern Öresund, and another with its source near the area discharges into the middle of the strait.

\section{Settlement along the Öresund strait}

The finds from the Rönneholms Mosse bog are dated to the Middle Mesolithic. It was at this time that the sea level in southernmost Sweden reached the equivalent of today's level. The fact that there were contacts between the coast and inland earlier than this is indicated by a find of a seal tooth and other grey seal bones at a settlement site of Maglemose culture on the edge of the Ageröds Mosse bog, which is part of the same complex of bog land (Lepiksaar 1978).

At the submarine outflow of the River Saxån, roughly in the middle of the Öresund, the remains of now-sub- merged settlements of Maglemose culture have been found (Larsson 1983b, 2017a) (Fig. 9).

The area between present-day Landskrona and the island of Ven turned out be a suitable area for finding submerged settlements from earlier periods of the Mesolithic. The bottom topography shows a river channel from the present-day outflow of the River Saxån several kilometres south of the town. The submerged river can be followed though the harbour of Landskrona, and at least half-way out to the island of Ven.

In order to obtain further information on coastal settlements formed during an earlier part of the Mesolithic, marine archaeological investigations were carried out on the Swedish side of Öresund (Larsson 1983b). They concentrated on corresponding to the prehistoric course of the River Saxån. Along the submarine channel of the river, both surveys and a small excavation revealed a number of sites.

At least three Early Mesolithic sites were recorded during this preliminary investigation, the depths of which 

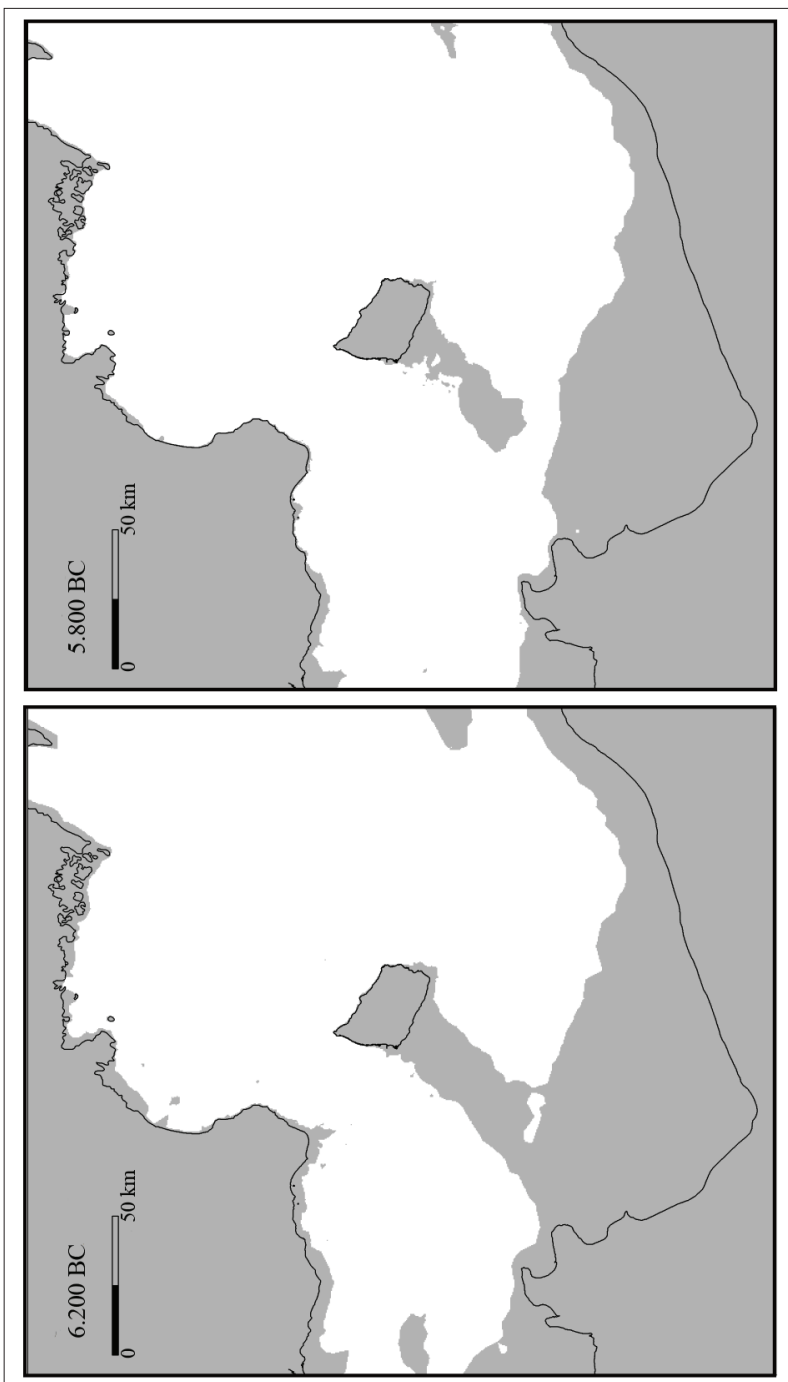

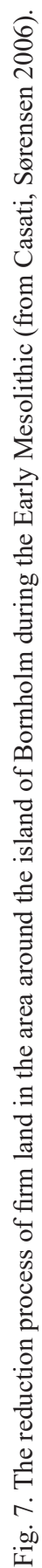

记

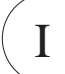

STONE AGE

IN NORTHERN

EUROPE:

CHANGES IN

LANDSCAPE,

TECHNOLOGIES

AND BELIEFS

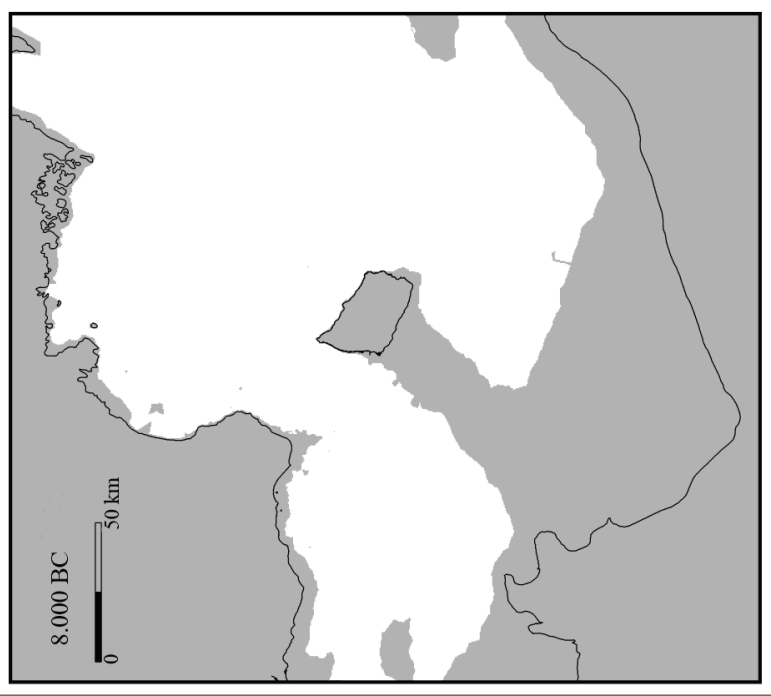




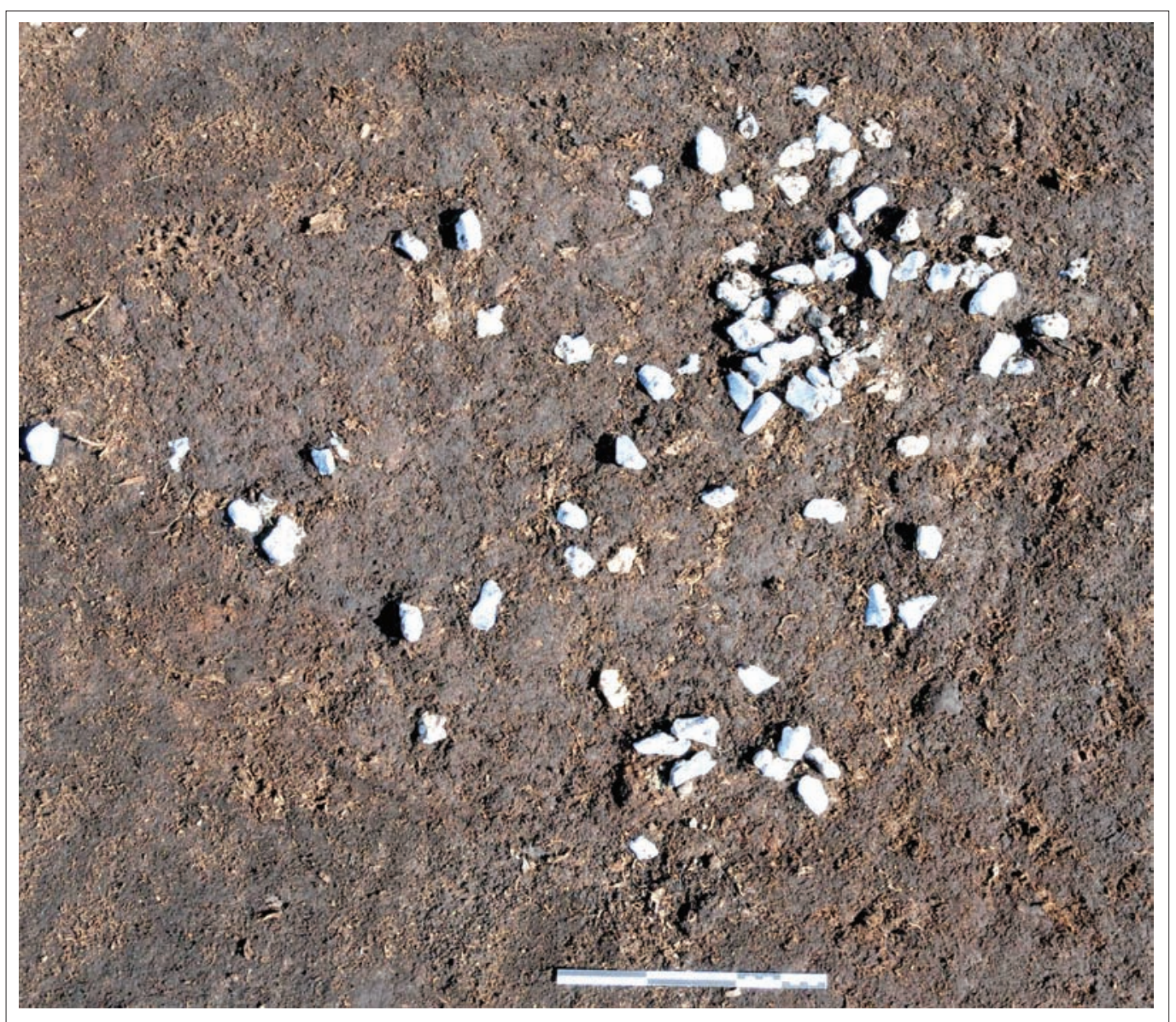

Fig. 8. Accumulations of small flints, almost square and usually wave-washed, found at a site in the Rönneholms Mosse bog. The explanation is that they were attached as weights to nets made on the coast which have decomposed (photograph by Arne Sjöström).

varied between 20 metres and six metres below sea level. The somewhat raised bank named Pilhaken to the west of the former river outlet revealed more concentrations of artefacts than the east bank.

In the early 1990 s, a further site was located on Pilhaken, at the outermost part of the former river mouth. This site, which is partially covered in peat, was situated at a depth of seven to eight metres, and yielded artefacts and samples of oak and hazelnut dated to 7000 BCE (Fischer 1993). The site was located directly adjacent to the clearly marked course of the river.

An investigation of the site was accordingly carried out (Larsson 1999). The location of the site, exposed to winds and currents and close to extensive boat traffic, made the investigation work extremely difficult and time-consuming.

The majority of the flint artefacts were found in the lower part of a peat layer. The finds consist of flakes, blades and micro-blades, and a smaller number of implements, including scrapers, a burin and a burin spall. The previous underwater investigation of the site in 1992 had revealed a number of blades and micro- blades. A small number of bones from roe deer, red deer and aurochs were also found. The finds include a worked branch and sticks with traces of fire.

The settlement remains at Pilhaken are not the only ones on the east side of Öresund. In conjunction with prospecting on the sea bed associated with the building of a new bridge connecting Denmark and Sweden, surveys yielded flints that were dated to the Late Boreal (Fischer 1993; Denkert et al. 1994). However, none of these flints could be confirmed with certainty as in situ finds. Most also bore traces of rolling and salt water patination. The find material includes both blades and micro-blades dating from a late part of the Boreal and the earlier part of the Atlantic, i.e. a late period of Maglemose culture and the earliest part of Kongemose culture (Fischer 1993). The finds emerged at a depth of between nine and five metres. The inundation threshold in Öresund lies at this level, which indicates that significant quantities of salt water only found their way into the Baltic basin after that time.

Besides these underwater archaeological investigations, a number of other finds suggest settlement below the present sea level. At Segebro, immediately to the 


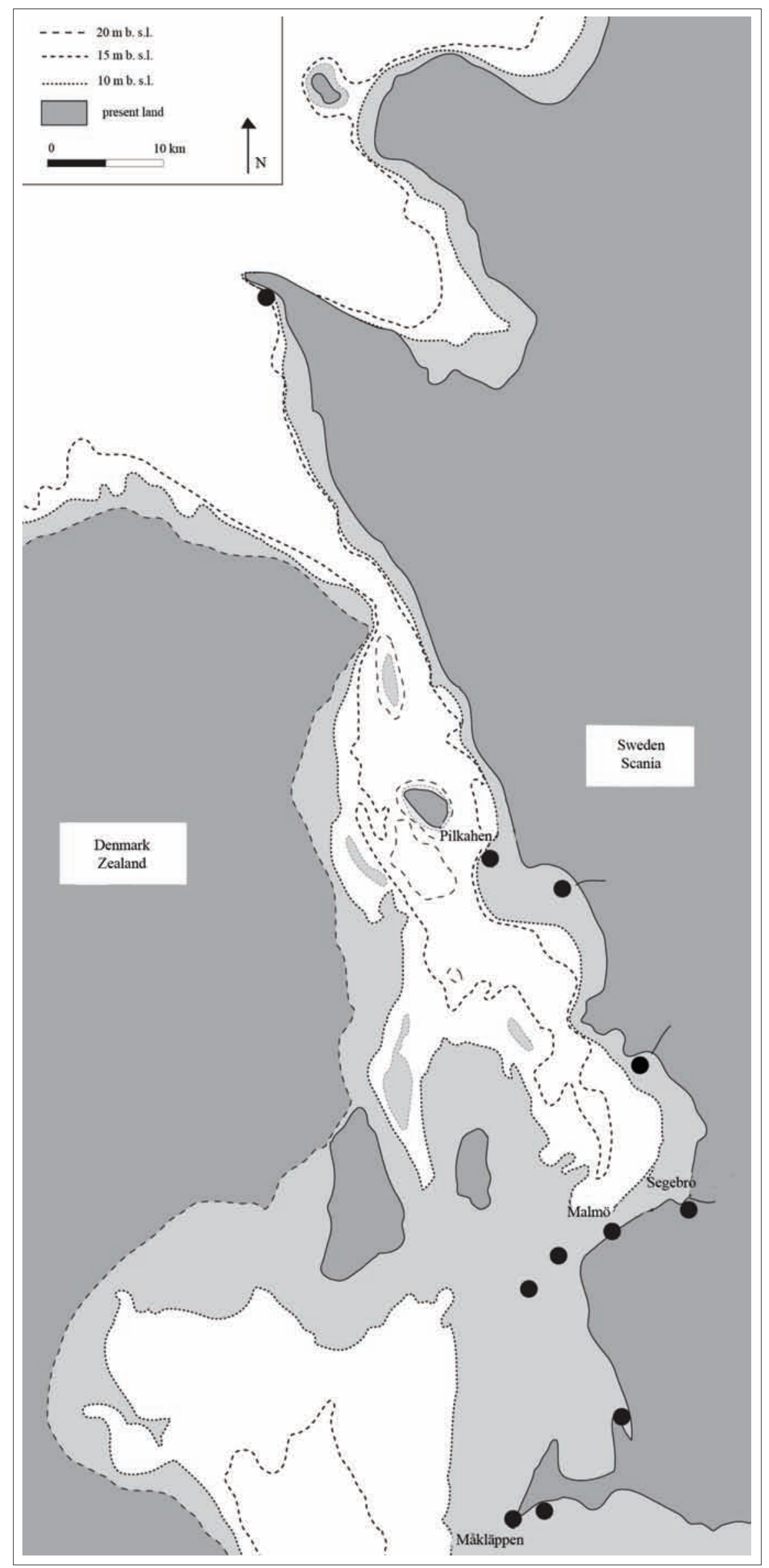

Ư

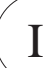

STONE AGE

IN NORTHERN

EUROPE:

CHANGES IN

LANDSCAPE,

TECHNOLOGIES

AND BELIEFS

Fig. 9. Find locations from submerged Early Mesolithic settlement sites along the east coast of the Öresund strait (from Larsson 2017a). 
north of Malmö, extensive deposition of sand during the Late Atlantic and Sub-Boreal resulted in the preservation of a variety of remains of a settlement from the Atlantic period (Larsson 1982) (Fig. 9). The occupation layer is situated at a shallow depth, between zero and minus one metre in the outer part of a river delta, and dated to about $6000 \mathrm{BCE}$. Measurement of ${ }^{13} \mathrm{C}$ in human remains gave values of $-16.7 \%$ and $-15.7 \%$, which shows that the inhabitants had a considerable intake of marine food. Grey seal is important among the bone finds, as is cod (Lepiksaar 1982).

As a result of expansion within the present harbour of Malmö, on the southeast side of Öresund, a large area of the sea bed was exposed before construction (Hammarstrand Dehman 2009) (Fig. 9), and uncovered parts of the original land surface, with fallen tree trunks and tree stumps still in place at a level of minus two to minus one metres. According to radiocarbon dates and dendrochronological analysis, a mixed, dense forest was still standing at 6200-6100 cal. BCE (Hardevik et al. 2008). After 120 to 140 years, the area became wetter, and oak was replaced by alder. This change occurred within 11 to 75 years, depending on the sampling points. Artefacts were found at the original surface level, but no real settlement site. Fish traps were found, and are dated to the interval 5750-5550 cal. BCE.

Amber is abundant on the beaches of the southernmost part of Öresund, close to the small towns of Skanör and Falsterbo. While collecting pieces of amber, an amber craftsman who is also an amateur archaeologist collected bones and worked flints, mostly found on the western side of the small island of Måkläppen (Larsson, Brost 2011). The fact that heavy erosion of organic layers on the sea bed is in progress is evident from the pieces of peat that are washed up in large quantities on the beach during winter storms.

Several human bones were identified, as well as large flint blades. One find, a femur bone, was dated to about 6000 BCE. The bone might have belonged to a settlement site or a grave that could have been destroyed by currents and washed up on the beach. The bone finds have a ${ }^{13} \mathrm{C}$ value of $-14.5 \%$, indicating that marine food was of primary importance.

\section{Shore displacements in a mental context}

As stated before, the rise in sea level had various consequences. A rise of at most four metres of the southernmost part of Sweden in the later Atlantic period through transgressions in different stages meant that areas of present land were drowned.
On the coast at Skateholm, in southernmost Sweden, this had the result that the coastline was not shortened. On the contrary, it became longer, because a lagoon was formed. This sort of extended coastline arose not just at Skateholm, but also elsewhere on the south coast, where lagoons of varying sizes arose, and where there were big and small archipelagos for periods of varying duration (Larsson 1993). At Skateholm, we have the oldest-known find spot, with remains of settlement and cemeteries from around 5200 BCE on an oblong island (Skateholm II), which was completely flooded after a few centuries (Fig. 10). Then the settlement and its burials were moved to a nearby island (Skateholm I), which was likewise submerged in the Late Atlantic period. At a place a few hundred metres further from Skateholm I, probably yet another large settlement, possibly with burials (Skateholm IX), might have existed at a time somewhat younger than Skateholm I. Then a larger settlement with a burial ground was established on a nearby sand ridge (Skateholm III), which was partly flooded, forcing the settlement to move further into the lagoon, where at least one large settlement was established. This shows that the lagoons which had expanded through transgressions were attractive, despite the rather frequent moves of the settlements.

But it was not just tangible facts that affected coastal settlers. In Skateholm, as at other attractive lagoons, the distance between settlements of different ages is not especially great, at most a couple of hundred metres. Shifts of the shoreline must have been noticeable in the course of a generation or two. The fact that not only the settlement had to move, but also, and above all, the fact that an older cemetery was gradually submerged by water, must have left deep marks in people's perception of the world. In a society with a narrative account of history, it was possible to describe to younger generations where older relatives were buried, and the place could even be pointed to where they were buried at the bottom of the lagoon (Larsson 2017a). There were surely stories about how other, even older, settlements and graves had been inundated in earlier lagoon settings. Since this had been going on for hundreds, if not thousands, of years, this information must have been absorbed by their imaginations. We may wonder what taboos and rules of conduct may have existed concerning this changing world, and how fishing on and near former burial places was affected. New excavations suggest a powerful relationship to the ancestors in that the filling in graves in certain cases consisted of occupation layers from earlier settlements (Larsson 2017b).

In areas where new landmasses replaced former water surfaces, the world-view was different. We can only 


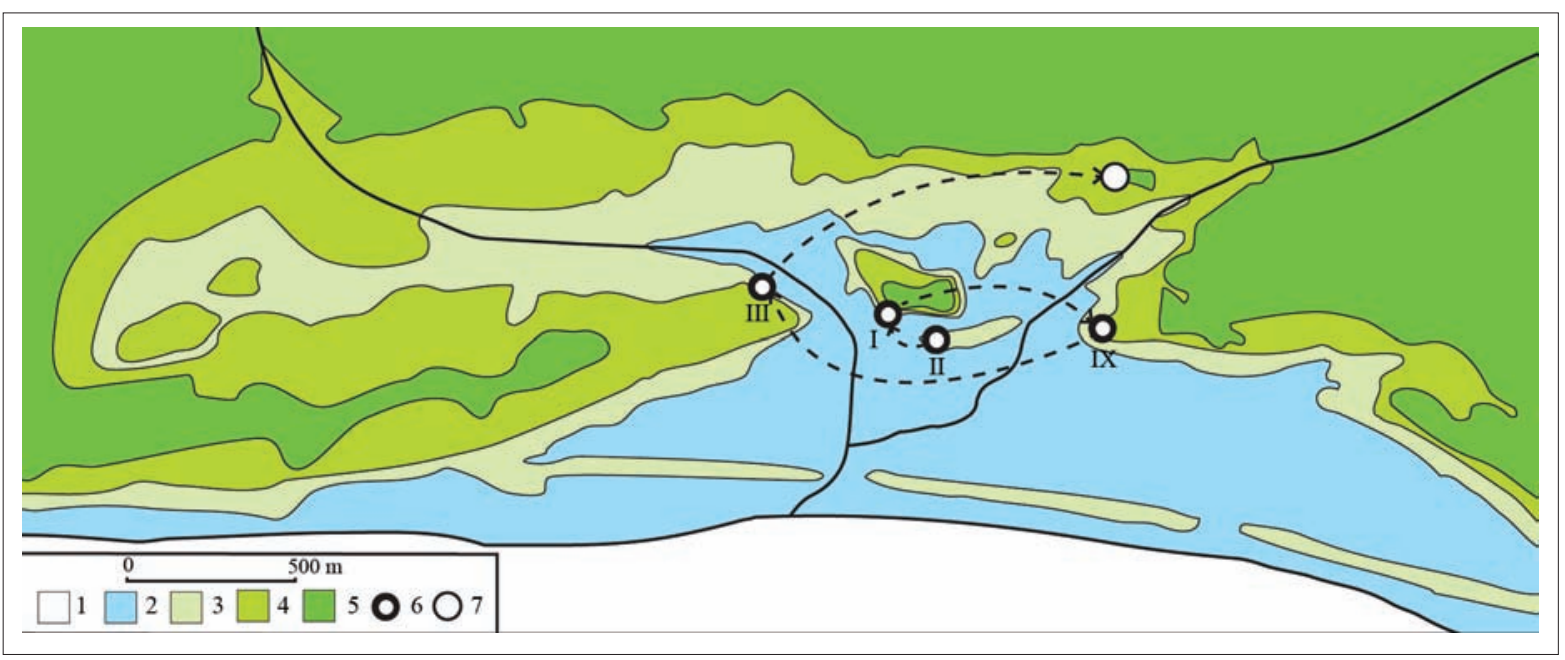

Fig. 10. The relation of land and sea during stages of the Late Mesolithic. Legend: 1, present sea level; 2, the situation during the occupation of Skateholm II (2 to $3 \mathrm{~m}$ a.s.1.); 3, the situation during the occupation of Skateholm I (3 to $4 \mathrm{~m}$ a.s.1.); 4: the situation during the occupation of Skateholm III (higher than $4 \mathrm{~m}$ a.s.1.); 5, large settlement site with cemetery and 6 , large settlement site.

speculate on how these different relations to the coastal environment were affected when people from the south and the north met.

\section{Conclusions}

The effect of isostasy and eustasy is that the state of our knowledge regarding coastal settlement along the east and south coast of Sweden in the Early and Middle Holocene varies greatly. The aim has been to focus on some points in time to gain an insight into the differing conditions for coastal settlement based on a number of excavations. These can be based on projects with specific objectives, such as studies of the earliest settlement on Gotland, or the results of marine archaeology in southernmost Sweden. But they can also be contract excavations occasioned by development, for example, the Strandvägen find place beside Lake Vättern, and Norje Sunnansund in southeast Sweden.

On the long west coast of the Baltic Sea basin, the conditions for coastal settlement differed greatly. In the north, the land rose at a speed that must have been noticeable to the inhabitants. This meant that settlements moved once or twice within one generation, depending on the topographical conditions. Customary hunting places, and perhaps also the forms of hunting, altered as a result of changes to the mainland coast and the archipelagos close to the land or far out from it. Finds from east central Sweden show that the outermost part of the archipelago was also part of an area often used for hunting.

The situation appears to have been different as regards the oldest settlement on Gotland, where eustasy and isostasy have had a complex effect on the form of the island. The main resource that seems to have enticed people to come to the island initially seems to have been the fishing in the nutrient-rich lakes. When these were transformed into bogs, the island lost much of its attraction, even though there ought to have been ample opportunities for hunting marine mammals. A possible reason for this is that hunting required fewer resources closer to the coast of the mainland, and the mainland had other animal resources not found on Gotland.

The dramatic eustasy combined with significant transgressions meant that large areas of coast were submerged by the Baltic Sea in southern Sweden. The changes could be observed within a human lifetime, requiring settlements to move. The pattern of movement, however, must have been limited within societies that were almost permanently connected to the coast. Changing coastlines may have provided different conditions, some of them leading to the drowning of lagoons with rich catches, or the creation of sandy beaches with little ecological variation, while new stretches of coast in other cases meant that places which had not previously been interesting were transformed into attractive hunting environments. The fact that settlement sites today are under water means that special and costly methods are required to investigate them, which seriously reduces our chances of largescale research efforts. The consequence is that we have limited knowledge about settlement. There is a great deal to suggest that this coastal settlement was extensive. The limited work that has been done to identify settlement in submarine environments suggests that settlements in the Early Mesolithic were in locations corresponding to those from the Late Mesolithic.

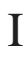

STONE AGE IN NORTHERN EUROPE: CHANGES IN LANDSCAPE, TECHNOLOGIES AND BELIEFS 


\section{References}

ANDERSON, K., 2005. Tending the Wild: Native American Knowledge and the Management of California's Natural Resources. Berkeley: University of California Press.

ANDRÉN, T., BJÖRCK, S., ANDRÉN, E., CONLY, D., ZILLÉN, L. and ANJAR, J., 2011. The Development of the Baltic Sea Basin During the Last 130 ka. In: J. HARFF, S. BJÖRCK and P. HOTH, eds. The Baltic Sea Basin. Heidelberg: Springer, 75-98.

APEL, J., WALLIN, P., STORÅ, J. and POSSNERT, G., 2017. Early Holocene human population events on the island of Gotland in the Baltic Sea (9200-3800 cal. BP). Quarternay International 2017.

BOETHIUS, A., 2016. Something rotten in Scandinavia: the world's earliest evidence of fermentation. Journal of Archaeological Sciences 66, 169-180.

BOETHIUS, A., 2017. Signals of sedentism: Faunal exploitation as evidence of a delayed-return economy at Norje Sunnansund, an Early Mesolithic site in south-eastern Sweden. Quaternary Science Reviews 162, 145-168.

BOETHIUS, A., STORÅ, J., HONGSLO VALA, C. and APEL, J., 2017. The importance of freshwater fish in Early Holocene subsistence: exemplified with the human colonization of the island of Gotland in the Baltic basin. Journal of Archaeological Science: Reports 13, 625-634.

BOND, G., KROMER, B., BEER, J. MUSCHELER, R., EVANS, R., SHOWERS, W. HOFFMAN, S., LOTTI-BOND, R., HAJAS, L. and BONANI, G., 2001. Persistent solar influence on North Atlantic climate during the Holocene. Science 294, 2130-2136.

BROOKS, S.J. and LANGDON, P.G., 2014. Summer temperature gradients in northwestern Europe during the Lateglacial to early Holocene transition (15-8 ka BP) inferred from chironomid assemblages. Quaternary International 341, 80-90.

CARLSSON, T., 2008. Where the river bends under the boughs of trees. Strandvägen - a late mesolithic settlement in eastern middle Sweden. Stockholm: Riksantikvarieämbetet.

CASATI, C. and SØRENSEN, L., 2006. Bornholm i ældre stenalder. Status over kulturel udvikling og kontakter. Kuml 55, 9-58.

COLES, B.J., 2006. Beavers in Britain's Past. WARP Occasional Paper 19. Oxford: Oxbow.

CROMBÉ, P., 2017. Abrupt cooling events during the Early Holocene and their potential impact on the environment and human behavior along the southern North Sea basin (NW Europe). Journal of Quaternary Science 2017.

CROMBÉ, P., 2016. Forest fire dynamics during the early and middle Holocene along the southern North Sea basin as shown by charcoal evidence from burnt ant nests. Vegetation History and Archaeobotany 25, 311-321.

DENCKER, J., HANSEN, J-S. and PETERSEN, S-B. 1994. Marinarkeologiske rekognosceringer efter fredede vrag og fortidsminder i Prøvegravnings- og Prøveomraderne. København: Miljøministeriet, Skov- og Naturstyrelsen.

ERIKSSON, G., FREI, K.M., HOWCROFT, R., GUMMESSON, S., MOLIN, F., LIDÉN, K., FREI, R. and HALLGREN, F., 2018. Diet and mobility among Mesolithic hunter-gatherers in Motala (Sweden) - The isotope perspective. Journal of Archaeological Science: Reports, 304-318.

FISCHER, A., 1993. Marinarkreologiske førundersøgelser forud for etablering af en fast Øresundsforbindelse. Stenaldersbopladser pa bunden af Øresund. Hørsholm: Miljøministeriet, Skov- og Naturstyrelsen.
FISCHER, A., 1995. An entrance to the Mesolithic world below the ocean. Status of ten years'work on the Danish sea floor. In: A. Fischer, ed. Man and Sea in the Mesolithic. Coastal settlement above and below present sea level. Oxbow Monograph. Oxford: Oxbow, 371-384.

GRIFFITHS, S. and ROBINSON, E., 2017. The $8.2 \mathrm{ka} \mathrm{BP}$ Holocene climate change event and human population resilience in northwest Atlantic Europe. Quartanary International 2017, 1-17

GRØN, O., 2012. Our grandfather sent the elk - some problems for hunter-gatherer predictive modelling. Quartär $59,175-188$.

GUMMESSON, S. and MOLIN, F. in press. Points of Bone and Antler from the Late Mesolithic settlement in Motala, eastern central Sweden. In: D. BORIC, ed. Mesolithic in Europe. Oxford: Oxbow.

GUMMESSON, S., HALLGREN, F. and KJELLSTRÖM, A. 2018. Keep your head high: skulls on stakes and cranial trauma in Mesolithic Sweden. Antiquity, 74-90.

HAMMARSTRAND DEHMAN, K., 2009. Våtmarksarkeologiska undersökningar i Malmö på senare år. Fornvännen 2009 (1), 1-16.

HANSSON, A., NILSSON, B., SJÖSTRÖM, A., BJÖRSK, S., HOLMGREN, S., LINDERSEN, H., MAGNELL, O., RUNDGREN, M. and HAMMARLUND, D., 2016. A submerged Mesolithic lagoonal landscape in the Baltic Sea, southeastern Sweden Early Holocene environmental reconstruction and shore-level displacement based on a multiproxy approach. Quaternary International 463, 110-123.

HANSSON, A., BJÖRCK, S., LINDERSON, H., RUNDGREN, M., NILSSON, B., SJÖSTRÖM, A. and HAMMARLUND, D., 2017a. Early Holocene landscape development and Baltic Sea history based on high-resolution bathymetry and lagoonal sediments in the Hanö bay, southern Sweden. In: G. BAILEY, J. HARFF and D. SAKELLARIOU, eds. Under the Sea: Archaeology and palaeolandscapes of the continental shelf. Cham: Springer, 197-209.

HANSSON, A., BJÖRCK, S., HEGER, K., HOLMGREN, S., LINDERSON, H., MAGNELL, O., NILSSON, B., RUNDGREN, M., SJÖSTRÖM, A. and HAMMALUND, D., 2017b. Shoreline displacement and human resource utilization in the southern Baltic Basin coastal zone during the early Holocene: New insights from a submerged Mesolithic landscape in south-eastern Sweden. The Holocene 2017, 1-17.

HADEVIK, C., HAMMARSTRAND DEHMAN, K. and SERLANDER, D., 2008. Malmö C Nedre - $i$ samband med byggandet av tunnel och ny stationsbyggnad. Malmö stad RAÄ 20 Skåne län. Malmö Kulturmiljö Enheten för Arkeologi Rapport 2008:030. Malmö: Malmö Kulturmiljö.

HARTZ, S., JÖNS, H., LÜBKE, H., SCHMÖLCKE, U., VON CARNAP-BORNHEIM, C., HEINRICH, D., KLOOSS, S., LÜTH, F. and WOLTERS, S., 2014. Prehistoric Settlements in the south-western Baltic Sea area and Development of the Regional Stone Age Economy. Final report of the SINCOS-II-subproject 4, Berichte der Römisch-Germanischen Kommission, 92 (2011), 77-210.

KJÄLLQUIST, M., BOETHIUS, A. and EMILSSON, A., 2016. Norje Sunnansund: boplatslämningar från tidigmesolitikum och järnålder: särskild arkeologisk undersökning 2011 och arkeologisk förundersökning 2011 och 2012, Ysane socken, Sölvesborgs kommun i Blekinge län. Karlskrona: Blekinge museum.

KLOOß, S., 2015. Mit Einbaum und Paddel zum Fischfang. Holzartefakte von endmesolithischen und frühneolithisch- 
en Küstensiedlungen an der südwestlichen Ostseeküste. Untersuchungen und Materialien zur Steinzeit in Schleswig-Holstein und in Ostseeraum 6. Kiel/Hamburg: Wachholtz.

KNUTSSON, H., KNUTSSON, K., MOLIN, F. and ZETTERLUND, P., 2015. From flint to quartz: Organization of lithic technology in relation to raw material availability during the pioneer process of Scandinavia. Quaternary International 424, 32-57.

LARSSON, L. 1982. Segebro. En tidigatlantisk boplats vid Sege ås mynning. Malmöfynd 4. Malmö: Malmö museer.

LARSSON, L. 1983a. Ageröd V. An Atlantic Bog Site in Central Scania. Acta Archaeologica Lundensia 8:12. Lund: Institute of Archaeology.

LARSSON, L., 1983b. Mesolitic Settlement on the Sea Floor in the Strait of Öresund. In: P. M. MASTERS and N.C. FLEMMMING, eds. Quaternary Coastlines and Marine Archaeology. Toward the Prehistory of Land Bridges and Continental Shelves. New York: Academic Press, 283-301.

LARSON, L., 1993. The Skateholm Project: late Mesolithic coastal settlement in southern Sweden. In: P.I. Bogucki, ed. Case studies in European prehistory. Boca Raton: CRC Press, 31-62.

LARSSON, L., 1995. Man and sea in Southern Scandinavia during the Late Mesolithic. The role of cemeteries in the view of society. In: A. FISCHER, ed. Man and Sea in the Mesolithic. Coastal settlement above and below present sea level. Oxford: Oxbox, 95-104.

LARSSON, L., 1997. Coastal Settlement during the Mesolithic and Neolithic Periods in the Southernmost Part of Sweden. In: D. KRÓL, ed. The Built Environment of the Coast Areas During the Stone Age. Gdansk, 12-22.

LARSSON, L. 1999. Submarine settlement remains on the bottom of the Öresund Strait, Southern Scandinavia. In: A. THEVÉNIN, ed. L'Éurope des derniers chasseurs. Èpipaléolithique et Mésolithique. Peuplement et paléoenvironnement de l'Épipaléolithique et du Mésolithique. Grenoble: CTHS, 327-334.

LARSSON, L., 2004. The Mesolithic period in southern Scandinavia: with special reference to burials and cemeteries. In: A. SAVILLE, ed. Mesolithic Scotland and its Neighbours. The Early Holocene Prehistory of Scotland and its British and Irish Context and some Northern European Perspectives. Edinburgh: Society of Antiquaries of Scotland, 371-392.

LARSSON, L., 2005. From blank spot to focal point. An eastern Swedish site from a south Scandinavian perspective. In: G. Gruber, ed. Identities in transition. Mesolithic Strategies in the Swedish province of Östergötland. Arkeologiska undersökningar skrifter 46. Stockholm: Riksantikvarieämbetet, 24-35

LARSSON, L., 2017a. Submarine Settlement in the Öresund, Western Scania, Southernmost Sweden. In: G, BAILEY, J. HARFF, and D. SAKELLARIOU, eds. Under the Sea: Archaeology and palaeolandscapes of the continental shelf. Cham: Springer, 165-175.

LARSSON, L., 2017b. The past in the past in the mortuary practice of hunter-gatherer: an example from a settlement and cemetery site in northern Latvia. Documenta Praehistorica XLIV, 334-345.

LARSSON, L. and BROST, L., 2011. Uppspolad forntid. Strandfynd av människor och deras redskap på Måkläppen. Ale. Hilstorisk tidskrift för Skåne, Halland och Blekinge 2011 (4), 25-31.

LARSSON, L. and SJÖSTRÖM, A., 2011. Bog sites and wetland settlement during the Mesolithic: Research from a bog in central Scania, Southern Sweden. Archäologisches Korrespondenzblatt 2011 (4), 457-472.

LARSSON, L. and SJÖSTRÖM, A., 2013. Mesolithic research in the central part of Scania, southern Sweden. In: $\mathrm{K}$. JOHANSEN and M. TORV, eds. man, his time, artefacts, and places. Collection of articles dedicated to Richard Indreko. Muinasaja Teadus 19. Tartu: University of Tartu, Institute of History and Archarology, 487-513.

LARSSON, L. and MOLIN, F., 2017. Symbols in the Late Mesolithic. Ornaments on bone and antler from Strandvägen, Motala, in Central Sweden. In: M. MĂRGĂRIT, and A. BORONEANT, eds. From Hunter-Gatherers to Farmers. Human adaptations at the end of the Pleistocene and the first part of the Holocene. Papers in Honour of Clive Bonsall. Targoviște: Cetatea de Scaun, 397-408.

LARSSON, L., SJÖSTRÖM, A, and NILSSON, B., a Lost at the bottom of the lake. Leister prongs from the Early and Middle Mesolithic found in the bog Rönneholms Mosse, southernmost part of Sweden. In: H. LÜBKE and D. GROß, eds. Working at the sharp end at Hohen Viecheln. From bone and antler to Early Mesolithic life in Northern Europe. In print.

LEPIKSAAR, J., 1978. Distribution of the classified bones in Ageröd I:HC. In: L. LARSSON Mesolithic Antler and Bone Artefacts from Central Scania. Papers of the Archaeological Institute, University of Lund 1977-1978, 56

LEPISAAR, J., 1982. Djurrester från det tidigatlantiska bopplatsen vid Segebro nära Malmö I Skåne (Sydsverige). In: L. LARSSON 1982, 105-128.

MOLIN, F., GRUBER, G. and HAGBERG, L., 2014. Motala - a North European Focal Point? In: F. RIEDE and M. TALLAVAARA, eds. Lateglacial and Postglacial Pioneers in Northern Europe. BAR International Series 2599, Oxford: Oxbow, 91-102.

MOLIN, F., HAGBERG, L. and WESTERMARK, A., 2017. Living by the shore: Mesolithic dwellings and household in Motala, eastern central Sweden, 5600-5000 cal BC. Journal of Archaeological Science: Reports 2017.

MASON, S.L.R., 2000. Fire and Mesolithic subsistence managing oaks for acorns in northwest Europe? Palaeogeography, Palaeoclimatology, Palaeoecology 164, 139-150.

NILSSON, T., 1967. Pollenanalytische Datierung mesolithischer Siedlungen im Randgebiet des Ageröds Mosse im mittleren Schonen. Acta Universitatis Lundensis, Sectio II, No. 36. Lund: Gleerup.

NORDQVIST, B., 2005. Husaby Klev. En kustboplats med bevarat organiskt material från äldre mesolitikum till järnålder. Rapport UV-Väst 2. Göteborg: Riksantikvarieämbetet.

PETTERSSON, P. and WIKELL, R., 2006. Mesolitiska boplatser i Stockholms Skärgård. Fiske och säljakt på utskären under 10000 år. Fornvännen 2006, 153-167.

PETTERSSON, P. and WIKELL, R., 2013. Tidigmesolitiska säljägare i Tyresta för 10000 år sedan. Späckbetong, gråsäl och tomtning på en kobbe i Ancylussjön 120 km från fastlandet, Fornvännen 2013, 73-92.

PETTERSSON, P. and WIKELL, R., 2014. Where the sky and sea are one. Close encounters with early seafarers and seal-hunters off the Swedish Baltic Coast. In: F. RIEDE and M. TALLAVAARA, eds. Lateglacial and Postglacial Pioneers in Northern Europe. British Archaeological Reports S2599. Oxford: Archaeopress, 103-119.

RASMUSEN, H.B., VINTHER, B.M. and CLAUSEN, H.B., 2007. The Early Holocene climate oscilliations recorded in three Greenland ice cores. Quarternary Science Review 26, 1907-1914.

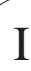

STONE AGE IN NORTHERN EUROPE: CHANGES IN LANDSCAPE, TECHNOLOGIES AND BELIEFS 
ROSENTAU, A., BENNIKE, O., USCINOWICZ, S. and MIOTK-SZPIGANOWICZ, G., 2011.The Baltic Sea Basin. In: N.C. FLEMMING, J. Harff, D. MOURA, A. BURGESS. and G.N. BAILEY, eds. Submerged Landscapes of the European Continental Shelf: Quaternary Paleoenvironments. Oxford: Wiley Blackwell, 103-133.

ROWLEY-CONWY, P., 1983. Sedentary hunters: the Ertebølle example. In: G.N. BAILEY, ed. Hunter-gatherer Economy in Prehistory. Cambridge: Cambridge University Press, 1-26.

ROWLEY-CONWY, P., 1993. Season and reason: the case for a regional interpretation of Mesolithic settlement patterns. Archeological Papapers of the American Anthropological Association 4, 179-188.

ROWLEY-CONWY, P. and ZVELEBIL, M., 1989. Saving it for later: storage by prehistoric hunter-gatherers in Europe. In: P. ALSTEAD and J. O'SHEA, eds. Bad Year Economics: Cultural Responses to Risk and Uncertainty. Cambridge: Cambridge University Press, 40-56.

SCHMÖLCKE, U., 2008. Holocene environmental changes and the seal (Phocidae) fauna of the Baltic Sea: coming, going and staying. Mammal review 38 (4), 231-246.

SEIFERT, T., TAUBER, F. and KAYSER, B., 2001. A high resolution spherical grid topography of the Baltic Sea 2nd edition. Baltic Sea Science Congress, Stockholm 2529. November 2001, Poster \#147, www.iowarnemuende. de/iowtopo

SWÄRD, H., O'REGAN, M., BJÖRCK, S., GREENWOOD, S.L., KYLANDER, M.E., MÖRTH, C.-M., PEARCE, C and JAKOBSSON, M., 2017. A chronology of environmental changes in the Lake Vättern basin from deglaciation to its final isolation, Boreas DOI 10.1111/bor.12288.

SØRENSEN, L. and CASATI, C. 2015. Hunter-gatherers Living in a Flooded World: The Change of Climate, Landscapes and Settlement Patterns during the Late Palaeolithic and Mesolithic on Bornholm, Denmark. In: S. KERNER, R. DANN and P. BANGSGAARD, eds., Climate Changes in Ancient Societies. Copenhagen: Museum Tusculanum, 41-68.

SØRENSEN, M., RANKAMA, T., KANKAANPÄÄ, J., KNUTSSON, K., KNUTSSON, H., MELVOLD, S., ERIKSEN, B.V. and GLØRSTAD, H., 2013. The First Eastern Migrations of People and Knowledge into Scandinavia: Evidence from Studies of Mesolithic Technology, 9th-8th Millennium BC. Norwegian Archaeological Review 1-38.

VON GRAFENSTEIN, U., ERLENKEUSER, H., MÜLLER, J., JOUZEL, J. and JOHANSEN, S., 1998. The cold event 8200 years ago documented in oxygen isotope records of precipitation in Europe and Greenland. Climate Dynamics 14, 73-81.

ZHILIN, M., 2015. Early Mesolithic Bone Arrowheads from the Volga-Oka Interfluve, Central Russia. Fennoscandia archaeologica XXXII, 35-54.

Received: 12 February 2018; Revised: 3 March; Accepted: 12 April 2018

Lars Larsson

Department of Archaeology and Ancient History

Lund University, LUX

Box 192 SE-221 00

Lund, Sweden

Lars.Larsson@ark.lu.se
ŽMONĖS, GYVENĘ PRIE

BESIKEIČIANČIOS JŪROS.

MEZOLITO GYVENVIETÉS

VAKARINIAME BALTIJOS

JÜROS KRANTE

\section{LARS LARSSON}

\section{Santrauka}

Pasitraukus paskutiniam Šiaurès Europą dengusiam ledynui, žemę pradejo veikti glacioizostaciniai procesai, kurie paspartino paviršiaus kilimą. Kaip to padarinys èmė keistis ir dabartinès Baltijos jūros pavidalas. Dèl poledyninių procesų i Baltijos ledyninị ežerą pradejjo veržtis Atlanto vandenyno vanduo, ir ežeras ilgainiui tapo sūriavandene Joldijos jūra. Borealio laikotarpiu ją pakeitè gèlavandenis Ancyliaus ežeras, o atlančio - besiskverbiantys Atlanto vandenyno vandenys suformavo Litorinos jūrą. Šios Baltijos jūros stadijos stipriai veikè tuo metu prie krantų gyvenusias mezolito bendruomenes (1-4 pav.). Tai turèjo įtakos jiems renkantis gyvenamają vietą ir ūkio modelị. Šiame straipsnyje pateikiami kai kurie atvejai, akcentuoti pietinès Švedijos Baltijos jūros pakrantèje, iliustruojantys įvairius būdus, kuriais medžiotojų-rinkėjų grupès buvo susijusios su pakrantės ekologiniais veiksniais mezolito laikotarpiu. Teritorijos transformacijos dažniausiai vyko dèl izostatinių ir eustatinių pokyčių. Šiaurinèje dalyje žemė pakilo, formavosi naujos pakrantès ir salynai, jų kaita buvo pastebima net per žmogaus gyvenimo trukmę (5-8 pav.). Panašūs greiti pokyčiai vyko pietiniame rajone, tačiau priešinga kryptimi - didelès pakrantès zonos paniro. İvairūs Baltijos jūros regionai holoceno pradžioje jūros vandens lygio kitimo buvo veikiami nevienodai $(9,10$ pav.). 